\title{
Benign and malignant pathology in neurofibromatosis type 1
}

\author{
Melanie Walker, MD; and Patrik Gabikian, MD
}

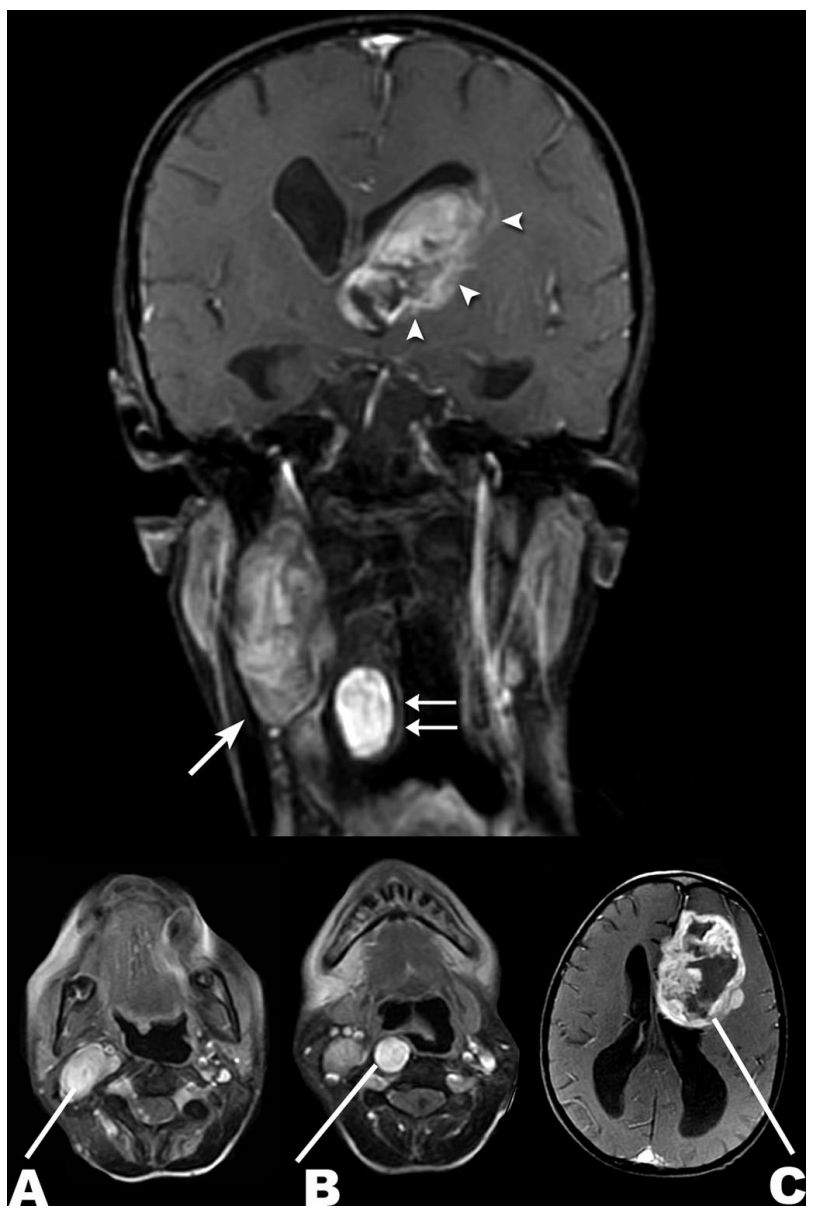

Figure. (Top) Gadolinium-enhanced coronal MRI of the brain revealed ventriculomegaly, right carotid sheath (arrow) and retropharyngeal nerve sheath tumors (double arrows), and a large heterogeneous left frontal mass with intraventricular extension (arrowheads). The extracranial lesions represent benign tumors seen in neurofibromatosis type 1. The left frontal mass was determined to be a gliosarcoma. (Bottom) Gadolinium-enhanced axial MRI reveals further detail of carotid sheath tumor (A), retropharyngeal nerve sheath tumor (B), and frontal gliosarcoma $(C)$.
A 25-year-old man presented for evaluation of aphasia and generalized seizures. Examination revealed café au lait macules, axillary freckling, and bilateral Lisch nodules. Surgical history included excision of an upper extremity plexiform neurofibroma and optic glioma resection followed by whole-brain radiation 20 years previously. His mother and maternal grandmother had also been diagnosed with neurofibromatosis type 1 (NF1). Recent onset signs and symptoms were attributed to the frontal mass, biopsy proven to be gliosarcoma. Malignant gliomas can arise as a late consequence of whole-brain radiotherapy or result from malignant degeneration of previously benign tumors in patients with $\mathrm{NF} 1^{1,2}$ figure.

\section{References}

1. Korf BR. Malignancy in neurofibromatosis type 1. Oncologist 2000;5:477-485.

2. Ruggieri M, Packer RJ. Why do benign astrocytomas become malignant in NF1? Neurology $2001 ; 56: 827-829$. 


\section{Neurology}

\section{Benign and malignant pathology in neurofibromatosis type 1 Melanie Walker and Patrik Gabikian \\ Neurology 2006;67;E13 \\ DOI 10.1212/01.wnl.0000237339.82395.a3}

This information is current as of September 25, 2006

\section{Updated Information \&} Services

References

Subspecialty Collections

Permissions \& Licensing

Reprints including high resolution figures, can be found at: http://n.neurology.org/content/67/6/E13.full

This article cites 2 articles, 2 of which you can access for free at: http://n.neurology.org/content/67/6/E13.full\#ref-list-1

This article, along with others on similar topics, appears in the following collection(s):

All Oncology

http://n.neurology.org/cgi/collection/all_oncology

MRI

http://n.neurology.org/cgi/collection/mri

Neurofibromatosis

http://n.neurology.org/cgi/collection/neurofibromatosis

Primary brain tumor

http://n.neurology.org/cgi/collection/primary_brain_tumor

Information about reproducing this article in parts (figures,tables) or in its entirety can be found online at:

http://www.neurology.org/about/about_the_journal\#permissions

Information about ordering reprints can be found online:

http://n.neurology.org/subscribers/advertise

Neurology ${ }^{\circledR}$ is the official journal of the American Academy of Neurology. Published continuously since 1951, it is now a weekly with 48 issues per year. Copyright. All rights reserved. Print ISSN: 0028-3878. Online ISSN: 1526-632X.

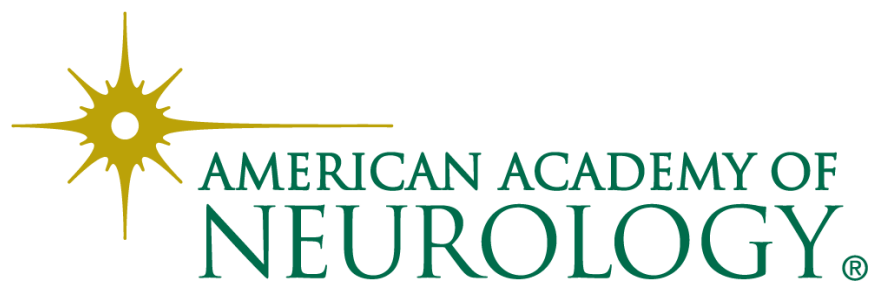

